\title{
VRIJHEID EN ONZEKERHEID INZONDERHEID BIJ RUDOLPH BULTMANN
}

1. In contemporaine West-Europese filosofie en theologie treffen wij als een grond-zekerheid aan, dat er, zo zeker als de mens mens, de wereld wereld, en God God is, geen grondzekerheden kunnen bestaan. Want de mens is in de kern van zijn mens-zijn vrijheid als vrije beslissing in het concrete heden. Aan dit karakter der beslissing zou onherstelbaar letsel zijn aangebracht, wanneer zij niet riskant zou zijn, een „Wagnis", gericht op de onzekere toekomst.

Tegelijk zou aan de irrationaliteit, haar duisternis en onberekenbaarheid van "de wereld" en 's werelds verloop onherstelbaar letsel zijn toegebracht, indien 's mensen ontmoeting met de wereld niet de ontmoeting met een donker „Schicksal" zou zijn, dat ons temidden van de onzekerheden moet werpen.

En voorts zou God Zijn goddelijke vrijheid kuijt zijn, indien Gods openbaring zou inhouden, dat $\mathrm{Zijn}$ openbaren zou resulteren in een ge-openbaard-heid, waardoor wij zeker wisten, wie en wat wij aan God hebben. Duidelijk schrijft Bultmann dit neer in de volgende uitspraak: „Seine (n.l. Gods) Offenbarung ist Offenbarung nur in actu und wird nie zur Offenbartheit" (Glauben und Verstehen, III, 120/121).

's Mensen streven naar "Sicherung" is voor Bultmann de grond, waarom de openbaring van God in het kruis van Christus, en het geloof hierin, een skandalon moeten zijn voor de mens, en waarom het christelijk geloof nooit anders dan iets bevrcemdends kan zijn, en dit altijd zal moeten blijven (G.u.V., III, 211). Karl Jaspers' verzet tegen het geloof in Gods openbaring, die verbonden zou zijn met een historische gebeurtenis (die van Jezus van Nazareth en zijn kruisdood) is z.i. het gevolg hiervan, dat Jaspers niet bereid is, „sich gegenüber dem ihm hier und jetzt begegnenden Wort Gottes völlig zu entsichern" (G.u.V., III, 211). En Bultmann gaat dan als volgt voort: „Er (n.l. Jaspers) sichert sich gleichsam durch eine Metaphysik, in der vorgezeichnet ist, wann und wo Gott reden könne. Es scheint mir, dasz er um seiner Selbstsicherung willen Gott, der immer nur ein auf mich zukommender Gott sein kann, zu einer zeitlosen Welt des Geistes vergegenständ- 
licht, über die der Mensch denkend verfügen kann" (a.w., 212).

Jaspers zou zich dus niet geheel en al willen "entsichern". Dat dit voor Jaspers, volgens Bultmann, kwalijke gevolgen moet hebben, blijkt wel uit Bultmann's leer, dat de „eigenlijke" vrijheid slechts dan den mens ten deel kan vallen, wanneer hy door de vergevende genade Gods, die hem steeds opnieuw moet worden "toegesproken" in de verkondiging, $b c$ vrijd wordt van zichzelf, en dusdoende bevrijd wordt van eigen verleden, van eigen zelf-verzekering en van eigen werken, waarmee hij zichzelf tracht te verzekeren en te handhaven; ten einde open te staan voor... de toekomst, die allereerst de toekomst van de op hem toe komende God is. Vrijheid is voor Bultmann de openheid voor de toekomst, die op ons af komt, voor de op ons af komende ontmoeting met medemens, "Schicksal" en met God. Deze openheid involveert, dat wij van onszelf bevrijd zijn, d.i. van ons verleden; en deze bevrijding van onszelf houdt allereerst in, dat wij bevrijd zijn van onze zelf-verzekering, onze zelfbescherming tegen de toekomst en wat en wie ons daarin tegemoet kunnen treden; zij houdt de zelf-overgave en zelf-prijsgave in: tegendeel van de "Selbstsicherung". Wie niet waagt, en d.i. hij wie zichzelf niet waagt, is niet vrij voor de toekomst, en dus niet vrij; maar is aan zichzelf vastgeklonken, en klinkt zich aan zichzelf vast. Hij is een gevangene, en nog wel de gevangene van zichzelf. De keerzijde van de médaille der vrijmaking is de "Entsicherung” van zichzelf.

2. Bultmann heeft in één van zijn talloze artikelen de vrijheid eens als volgt omschreven: „Freiheit ist keine natürliche Eigenschaft des Menschen, sondern sie ist nur jeweils Ereignis, und sie wird Ereignis da, wo der Mensch durch das Wort der Vergebung von sich selbst befreit ist und dadurch offen für die ihm im Nächsten begegnende, Antwort heischende Frage" (G.u.V., III. 126).

Gecompleteerd wordt deze omschrijving door zijn leer, dat de mens ook als (vrije) persoon heeft te existeren in de ontmoeting met „,as Schicksal": „Wie ich ein Schicksal aufnehme und bestehe, mich ihm öffne oder verschliesze, ist immer jeweils Sache der Entscheidung" (G.u.V., III, 118).

Het beeld van B's vrijheidsidee wordt na het vorengaande nog eens verduidelijkt door wat $B$. schrijft over de taak der theologie in de huidige situatie. Zij zou z.i. moeten duidelijk maken, dat het christelijk geloof geen ,innerweltliche Sicher- 
keit gibt, dasz er aber, als der Glaube an Gottes offenbare Gnade, die Freiheit schenkt, getrost durch Dunkelheit und Rätsel hindurchzuschreiten und die Verantwortung für die Tat in der Einsamkeit eigener Entscheidung zu wagen und $\mathrm{zu}$ tragen" (G.u.V., III, 196).

Wanneer hier gezegd wordt, dat vrijheid geen natuurlijke eigenschap van de mens is, is hiermee niet bedoeld, dat zij een bovennatuurlijke eigenschap van de mens zou zijn. Immers, B. stelt zelf tegenover „,een natuurlijke eigenschap" het „Ereignis”, een gebeuren, dat steeds opnieuw wordt en gáát beginnen. Elders heeft hij dan ook de Griekse, resp. antieke en de christelijke opvatting van vrijheid zo met elkander gecontrasteerd, dat z.i. de antieke denkers er geen besef van hebben gehad, dat de vrijheid iets anders is dan een (geestelijke) eigenschap van de mens, en dat eerst het christendom de vrijheid als een "geschichtliches Ereignis" heeft gezien en geleerd. De Oudheid zag de mens als een redelijk wezen, 's mensen vrijheid als een ethische, zedelijke eigenschap des mensen zodat er in het mensbeeld van de Grieken geen ruimte was voor de "Geschichtlichkeit des menschlichen Seins". De mens van het Griekse mensbeeld was een "ungeschichtlicher Mensch" (G.u.V., III, 155 e.v.).

De door B. bedoelde tegenstelling is derhalve die van „natuurlijk, constant onveranderlijk" met: „historisch", steeds nieuw, steeds oorspronkelijk, $z^{\prime} n$ oorsprong vindend in de Toekomst, en uit die Toekomst op ons afkomend. Zelf gebruikt hij hier graag en bij herhaling het woord "eschatologisch" voor. Vrijheid is "eschatologische" vrijheid.

Ten dezen staat $\mathrm{B}$. in voor de vrijheidsidee van alle existentie-filosofisch denken. Ook voor de mens-idee van alle existentie-filosofisch denken. Zijn visie op de mens, ook op "de mens en zijn wereld naar het oordeel van de Bijbel" (c.f. G.u.V., III, 151 e.v.) veronderstelt het existentie-filosofisch mensbeeld, en is zonder dit mensbeeld niet te verstaan. Dit mag wel eens met nadruk worden gezegd. Menig theoloog van vandaag is er op uit, te laten zien, dat o.a. de mens-leer en het mensbeeld van het Thomisme en van de post-reformatoren wezenlijk bepaald zijn door het antieke, veelal aristotelische mensbeeld, en daarom reeds verwerpelijk. Het is niet Bijbels, maar verfilosofeerd en veruereldlijkt. Ook B. gaat ons hier in voor. Maar de critische distantie tegenover eigen mensbeeld, dat dan Bijbels zou zijn, ontbreekt geheel en al. Zij zien niet, 
dat eigen mensbeeld en ook eigen "theologie over de mens in de Bijbel" in duigen valt, wanneer de existentie-filosofische ondergrond er aan wordt ontnomen, n.l. de leer, dat de mens de geschiedenis is van zijn eschatologische vrijheidsbeslissingen temidden van een contingente, irrationele wereld. Met deze bril op wordt door hen de Bijbel gelezen, zonder dat zij door hun eigen bril zien. Als ooit een theologie, en dan nog wel een zich Bijbels noemend theologie, die in exegese en in exegese alleen, dogma-vrij, meent te rusten, kind van eigen tijd is, dan is het deze theologie. Met haar hermeneutisch princiep van de existentieel-vrije mens als "Geschichtlichkeit". Zij meent hiermede, rationalisme en historisme te hebben overwonnen, maar ze staat weerloos tegenover de critiek van het historisme en bevestigt veeleer dit historisme, wanneer het historisme als gronddogma voor het "verstaan" van teksten poneert, dat iedere tekst naar haar wezenlijke, diepste betekenis niet meer en niet anders dan kind van haar tijd is en boven eigen tijd niet uit kan reiken. Dat zij dit doet, is droevig, maar niet minder waar.

Vrijheid zou een gebeuren zijn, dat slechts in de eenzaamheid der beslissing plaats vindt en gewaagd wordt, en voor welker riskante daad de vrije mens persoonlijk verantwoordelijk is zonder dat hij zich op enige instantie kan beroepen of enige "objectieve" steun kan vinden.

Sartre, Heidegger, Jaspers, Merleau-Ponty leren niet anders. Vrijheid eist - zo luidt de metafysische anthropologische grondregel van alle existentie-filosofie - volstrekte onzekerheid, een irrationele, afgrondelijke „Umwelt”. De vrijheid drijft de zekerheid, de zekerheid drijft de vrijheid voor zich uit.

De vrijheid eist de onzekerheid als haar onmisbaar element. En omdat B., evenals alle existentie-filosofen, opteert voor de vrijheid, drijft hij de zekerheid zowel uit de wereld als uit de Bijbel uit, en neemt het donkere, irrationele „Schicksal" een dominerende plaats in zijn exegese der H.S. en in zijn anthropologie in. Mens-zijn is vrij-zijn in een contingente, irrationele, onberekenbare en onherbergzame wereld. De mens schrijdt - zo lazen wij - door donkerheid en raadselen, en waagt dan de verantwoordelijkheid voor eigen daad in de eenzaamheid van eigen (vrije) beslissing. Die als beslissing nergens steun vindt, en nergens steun mag of kan vinden, omdat zij anders geen beslissing zou zijn. 
3. Evenals bij alle existentie-filosofie doemt hier dan een nieuwe radicale antithese op. De antithese tussen de eigenlijke en de oneigenlijke mens. De oneigenlijke mens zoekt steun, zoekt zekerheid, zelf-beveiliging, en verraadt en verloochent dusdoende eigen vrijheid en eigen vrijheidsroeping. Het ergste, wat B. in een mens kan constateren, is niet immoraliteit, maar is "Selbstsicherung", en de hiermee corresponderende onwil, om totaal "entsichert" te worden. Want de mens randt daarmede eigen wezen aan.

En evenals het er in de existentiefilosofie om gaat, om de mens op te roepen tot de wederkeer naar eigen „eigentlich" bestaan, naar een steeds opniew in vrijheid leven vanuit de toekomst, zo roept ook B. op tot de bekering uit eigen oneigenlijk bestaan, en tot een leven in en vanuit eigen ,eigenlijkheid", open voor de toekomst en bevrijd van eigen schuldbeladen verleden. God kan alleen zichzelf openbaren aan en teruille van deze eigenlijkheid van de mens, en Gods openbaring moet op deze eigenlijkheid van de vrije mens zijn afgestemd: de Godsopenbaring moet correlaat zijn met dit zelf-verstaan des mensen in zijn vrije eigenlijkheid, en zij moet deze eigenlijkheid honoreren en bedoelen.

In deze eigenlijkheid des mensen is hij verlost van alle "Uneigentlichkeit", en d.i. van de angst, die de bron is, de enige bron voor 's mensen gedurig pogen, om zichzelf te beveiligen en te verzekeren: kenmerk van de „oneigenlijke mens", de slaafse mens. Deze mens staat in een averechtse houding tegenover de geschiedenis, n.l. niet in de eschatologische houding. Zelfverzekering houdt een zich beveiligen voor de toekomst in, en is derhalve het tegendeel van de openheid voor de toekomst en het leven uit de toekomst.

Wanneer B. een wezenskenmerk van het christelijk geloof ziet in de "Entweltlichung", de ont-wereldlijking, dan blijkt deze "Entweltlichung" struktureel niets anders in te houden dan wat de existentiefilosofie in het Franse taalgebied aanduidt met „se dégager": de eigenlijke mens gééft zich aan iets doordat hij er zich tegelijk aan onttrekt, door het tegelijk dank zij de betrokkenheid op de toekomst "eschatologisch" te transcenderen; dan verschilt het in principe niet van wat in het Duitse taalgebied "das Transzendieren" wordt genoemd; en dan is het wezenlijk hetzelfde als wat Heidegger uitdrukt met: De mens is "das Wesen der Ferne". Daar zit niets christelijks in. 
B. moet dit zelf ook toegeven. Hij schrijft, dat deze vrijheidsidee ook buiten christelijk erf bekend is, ja, dat zij gemeengoed is van alle mensen: „Was Freiheit ist, weisz freilich auch der Mensch auszerhalb des Gluabens" (G.u.V., III, 183). Hij kán althans gemeengoed van alle mensen zijn. Het blijkt n.l. dat deze vrijheid, die ook als ,echte geschichtliche Entscheidung" kan worden omschreven, door de existentiale analyse wordt opgehelderd. Deze existentiale analyse heldert dan tegelijk op, wat echte geloofsbeslissing is, want de geloofsbeslissing draagt geen ander karakter (a.w., 183).

Dit wezenskenmerk van het christendom is derhalwe ook wezenskenmerk van de humaniteit des mensen naar de visie van theïstisch en atheïstisch existentialisme. Er zit niets specifieks christelijks in. Bultmann's ont-wereldlijking past dan ook, naar eigen bekentenis, geheel en al, binnen het raam van een „Existential-Analyse”, die het statuut van de mens bepaalt en dit statuut voor altijd bepaald heeft, onaantastbaar en oncorrigeerbaar door geloof in Gods Openbaring en door eventuele inhoud van deze openbaring Gods. Hij keert het zelfs steeds om, en eist, dat Gods openbaring naar vorm en inhoud binnen het raam van wat deze „Existential-Analytik" leert over de struktuur van het mens-zijn moet blijven, en dat het verstaan van de Heilige Schrift, zal het wetenschappelijk verantwoord zijn, van deze Existential-Analytik moet uitgaan, en binnen het kader van deze Analytik moet blijven. In deze eis is de reeds wereldkundige hermeneutische regel van de ontmythologisering begrepen. $\mathrm{Hij}$ is er een gevolg van. Eschatologische uitspraken der H.S., die heenwijzen naar een toekomst, waarin de mens niet langer een vrijmachtig ,geschichtlich" wezen zou zijn, dat zich temidden van een ongewisse, raadselachtige wereld bevindt, maar waarin de mens eens veilig zou wonen op een nieuwe aarde, kunnen niet letterlijk worden geloofd. $\mathrm{Zij}$ zouden de correlatie van vrijheid en onzekerheid doorbreken. Ze vragen dan ook om een interpretatie, die de "eigenlijke" zin er van moet onthullen. Zulk een interpretatie moet de tekst zo uitleggen, dat in elk geval nu cn immer de mens verkeert temidden van het donkere "Schicksal", waarbij de dood wel een fundamentele plaats inneemt, omdat hij principieel behoort tot de begrensdheid van de mens als mens. Zonder deze permanente begrensdheid, die een bedreiging is, kan de mens zich immers niet ,entweltlichen”, kan hij niet steeds opnieuw „eschatologisch" in het 
heden eigen verleden en de wereld transcenderen. $\mathrm{Ja}$, zonder deze begrensdheid door het irrationele "Schicksal”, dat zijn permanente onveiligheid is, zou hij ook niet als "uneigentlicher" mens in de doodzonde kunnen vallen van de "Selbstsicherung", de zelfbeveiliging. Welnu, evenals bij Heidegger de oneigenlijke mens de permanente voorwaarde blijft van het mens-zijn, ook van het "eigenlijke" mens-zijn, zo blijft ook de oneigenlijke mens der "Selbstsicherung" de permanente voorwaarde voor de "geloofsbeslissing" in het steeds nieuwe heden van de christgelovige, by Bultmann.

B.'s visie op het onderscheid tussen de mensvisie van de Oudheid en die van het christelijk geloof is derhalve primair en essentieel een weergave van het onderscheid tussen de mensvisie van de Oudheid en die van het moderne eigentijdse existentie-filosofisch denken. Waar hij in de Bijbel afwijking van dit mensbeeld moet constateren, „interpreteert" hij deze afwijking als mythe, en geeft hij zichzelf het recht, de tekst te ontmythologiseren. Een proces, dat eerst dan tot staan komt, wanneer wij weer bij het existentiefilosofisch grondpatroon van de mens aangeland zijn: de vrije, eschatologisch vrije mens, die in het heden van zijn vrijheidsbeslissing transcendeert naar de toekomst, en in die toekomst zijn oorsprong als mens heeft (de eindselen-leer als beginselen-leer; het einde als oor-sprong), temidden van een irrationele, duistere wereld, die alle zekerheid logenstraft en doet ineenstorten. Zo vindt hij in de Schrift, wat hij er in zocht; en zoekt hij in de existentie-filosofie, wat hij in de Schrift moet vinden. En zo valt hij het reformatorisch beginsel der Schriftinterpretatie af, waarvolgens de Schrift met de Schrift en met de Schrift alleen moet worden geïnterpreteerd. Hij interpreteert haar o.a. met de moderne mens en diens mensbeeld, gevormd door de existentie-filosofie.

4. Intussen hebben we hier met synthese-denken te doen. Vroeger kon zich dat nog wel als filosofie, of gedeeltelijk als filosofie aankondigen. Vandaag niet meer. Want zo goed als algemeen aanvaard is de stelling, dat filosofie per definitie geen filosofische theologie en ook geen theologische filosofie kan zijn. Heel anders dan bij Thomas van Aquino en bij het voorKantiaans rationalisme.

B.'s vrijheids-idee wordt een theologische vrijheidsidee; Bultmann's geschied-filosofische anthropologie wordt een geschied-theologische anthropologie, B.'s existentie-filosofie een 
existentie-theologie.

Uit de sub 2) geciteerde teksten blijkt dit. Het "Ereignis" der vrijheid valt den mens ten deel door het woord Gods der vergeving, of ook door het geloof aan Gods genade, die vrijheid schenkt.

De verbinding tussen beide, tussen deze filosofie en theologie, wordt door de paradox gevormd. De paradox scheidt niet, maar verbindt. Voor $\mathrm{K}$. Jaspers is de paradox juist het indicium van de verlegenheid, waarin Kierkegaard zich bracht, toen hij existentie-idee en geloof in Gods openbaring wilde verbinden. $\mathrm{Hij}$ is voor $\mathrm{K}$. Jaspers niet anders dan een asylum ignorentiae, zo niet een Deus ex machina.

Maar - hoezeer B. ook de degens met Jaspers gekruist heeft - hierop gaat B. niet in. Wanneer hij "paradox" gezegd heeft, is hij bevredigd. Gerechtvaardigd. Beveiligd. Verzekerd. Opzettelijk kies ik deze woorden. Omdat B's theologie, of liever, omdat B. in zijn theologie der paradox en wat hij aan inhouden aan de paradox, de christelijke, geeft, zich niet van deze zijn paradox laat „entsichern”, maar rust gevonden heeft telkens als hij bij de paradox is uitgekomen. De paradox is de alfa en de omega van de christelijke mens-, Gods-, Christus- en wereldbeschouwing van B. Hij staat er niet vrij tegenover; hij is er veilig in geborgen; hij gelooft er in; hij is de inhoud van zijn christelijk-theologistisch, intellectualistisch geloof. En dit geloofd theologisme moet bij $\mathrm{B}$. het christelijk geloof "redden".

B. inoculeert zijn "theologie" in de existentie-filosofie, inzonderheid in de "Existenzial-Analytik" van Heidegger's "Sein und Zeit". Hij neemt uit Heidegger's existenzial-analytische structuurleer van de mens het grondpatroon van de mens als "vrije mens in contingente, irrationele situatie" over en de hierbij passende leer van 's mensen "Geschichtlichkeit": een wezensbepaling van de mens als mens. Geen theologie, geen geloof, geen openbaring Gods zijn nodig, om dit mensbeeld te ontwerpen, of te legitimeren. En geen openbaring Gods, geen theologie, geen geloof en geen prediking mogen aan dit mensbeeld tornen. Het staat buiten discussie, is onaan tastbaar, en het eist, dat, zullen goddelijke openbaring en goddelijk heilswerk mogelijk zijn, deze openbaring en dit heilswerk aan het irrationele karakter van natuur en geschiedenis niets veranderen, en slechts betrokken zijn op de vrijheidskern van de mens en op 's mensen "geschichtliche" ver- 
houding tot natuur en geschiedenis. Een geloof in wonderen, in mirakelen, die natuur en geschiedenis niet aan eigen beloop en geslotenheid zouden overlaten, is derhalve contrabande. Het „Innerweltliche" blijft het „Innerweltliche": daar kan God niets aan veranderen. En wanneer de Schrift desondanks dergelijk mirakelgeloof leert, dan moet de Schrifttekst ontmythologiseerd worden, want de eigenlijke bedoeling van de Schrifttekst kan geen mythische zijn.

Wij moeten dus de H.S. ,verstaan" vanuit de vraag naar het "Woraufhin” der menselijke vrijheidskern, d.i. van de mens in zijn steeds ,gegenwärtige" verhouding tot natuur en geschiedenis, temidden waarvan hij tot zichzelf in een outonome verhouding staat.

De paradox kan aan deze voorwaarde niets af en niets toe doen. Dit betekent, dat wij volgens B. de Schrift (zo min als $B$. zelf) niet wetenschappelijk kunnen verstaan, indien wij Heidegger's Sein und Zeit niet als de onmisbare prolegomena op het verstaan der H.S. hanteren en respecteren. Het betekent, dat de exegeet geschoold moet zijn in de wijsgerige anthropologie van Heidegger.

Aan de overzijde echter van $\mathrm{H}$ 's mensleer ligt het specifiek theologische gebied, dat door de paradox a.h.w. gevrijwaard wordt tegen alle critiek, die vanuit de existentie-filosofische mensvisie zou kunnen worden uitgeoefend. De paradox beveiligt deze leer tegen deze critiek.

Inhoud van deze leer is de theologie inzake God, Die als de transcendente God uit $\mathrm{Zijn}$ toekomst in het heden tot ons komt in Christus door middel van de prediking, om met $\mathrm{Zijn}$ vergevende genade ons te bevrijden uit ons verleden, en ons open te stellen voor een vrije "Hingabe" aan ons „Schicksal” en voor een vrije, liefdevolle co-existentie en pro-existentie met de ons ontmoetende naaste, de medemens-,,in-der-Begegnung".

Kern van deze leer is, dat de mens wel kan weten, wat vrijheid is, maar uit zichzelf deze vrijheid niet deelachtig kan worden, doch door Gods vergevende genade alleen steeds opnieuw deze vrijheid verkrijgt als een bevrijding uit eiegen „oneigenlijkheid", d.i. uit eigen pogingen, om door denken en werken zichzelf te beveiligen tegen alle onzekerheid. Uit de last van dit verleden wordt hij paradoxaal door God bevrijd, doordat hij zichzelf in vrije geloofsbeslissing door God laat bevrijden. De paradox brengt de synthese tot stand. En 
met de synthese de eigenlijke eenheid van B.'s anthropologie. Lezen wij het eerste citaat sub 2 hier nog eens op na. Dan blijkt, dat de mens buiten de openbaring en Gods vergevende daad om wel van vrijheid kan weten, maar niet vrij kan zijn. Zijn vrijheid ontvangt hij steeds opnieuw in het heden der genade-openbaring Gods van Godswege. „Door het Woord der vergeving wordt de mens dan bevrijd van zichzelf" (G.u.V., 126). En alleen door het woord der genade wordt de vrijheid „Ereignis" (idem).

Geheel vol houden kan B. dit niet. Zo spreekt hij ook over de relatieve vrijheid, die 's mensen deel kan worden buiten het woord der prediking van Christus' kruis om. Ongetwijfeld een concessie, die hij niet kan verantwoorden vanuit zijn strenge conceptie. Maar voor het overige en dus doorgaans hebben wij met deze paradoxale mens te maken, die in de paradox van het heden der verkondiging van zichzelf bevrijdt wordt.

Ongetwijfeld werken hier motieven van Luther's leer van de rechtvaardigmaking door het geloof alleen. B. beroept zich hiervoor dan ook bij herhaling op Luther. En met Luther ziet hij de oneigenlijke mens vóór alles en principieel in de mens, die zichzelf garanderen, zichzelf beveiligen wil tegenover God door zijn wetsvolbrengen en derhalve door de werken der wet. Deze werken der wet zijn z.i. modern te vertalen in de werken, die de mens als redelijk-zedelijk wezen volbrengt; zijn zedelijke prestatie's. De mens der ,Aufklärung', die eigen gerechtigheid opbouwt door het ideaal van de zedelijke persoonlijkheid na te volgen, en die dit ideaal navolgt door aan de ",algemene waarheden" van een algemene levensleer (ethiek) als gedragsnormen te voldoen, is hier voor B. de oneigenlijke mens. Stellig is hier affiniteit met de existentie-filosofie, waarvoor ook de redelijk-zedelijke mens, de burgerlijke mens, de mens van de deugd der algemene plichtsbetrachting, de oneigenlijke mens is, die eigen vrijheid verloochent en daarmee eigen concrete persoonlijkheid en verantwoordelijkheid, door zichzelf onder het juk van een algemene ethiek te laten doorgaan. Als deugdzaam burger weet hij zo aan eigen zelfrechtvaardiging te bouwen.

Maar bij B. komt hier dan een theologische kroon op, ja, dit wordt door hem theologisch toegespitst. De Farizeeër verschijnt dan op het toneel. Die zich door eigen gerechtigheid tegen het oordeel van God veilig stelt, en derhalve geen be- 
vrijdende vergeving en genade van God meent nodig te hebben. $\mathrm{Nu}$ is het in B.'s "theologische anthropologie" zo, dat ieder mens, buiten de ontmoeting in het actuele heden der verkondiging van Gods vergevende genade om, niet anders dan een Farizeeër kan zijn, en zich derhalve permanent gedraagt als iemand, die zichzelf beveiligt tegen Gods oordeel, en die derhalve in zichzelf roemt voor Gods aangezicht. Zijn hele leven bestaat in het opbouwen van deze zijn „Selbst-Sicherung". Zijn doen en zijn denken zijn door deze impuls gedreven. Het gevolg is, dat hij niet open staat voor de toekomst, die immers als "Schicksal" niet anders dan ongewis kan zijn, zo min als voor de op hem toe komende God, Die niet anders dan een vergevend God kan zijn, en die enkel een vergevend God kan zijn, doordat Hij niet anders dan een ,immer nur ein auf mich zukommender Gott sein kann" (III, 212), en Wiens transcendentie en eeuwigheid niet anders dan "Geschichtlichkeit” kán zijn (b.v. III, 156 e.v.), „ständige Zukünftigkeit" (III, 121). In deze Zijn eschatologische advent tot de mens, die in de prediking "gebeurt", wordt de mens van zichzelf bevrijd, en d.i. van zijn "Selbst-Sicherung" (b.v. III, 163), van zijn wil, eigen leven zelf te kunnen „sichern” (210).

De vergevende genade Gods en haar bevrijding uit de wil tot zelf-beveiliging tegenover God, de toekomst van het „Schicksal" en de "Anspruch" van de medemens, die hem zal ontmocten, heeft derhalve bij $\mathbf{B}$. geen effectieve gevolgen in deze werkelijkheid. Het "heden" van deze genade en van het hiermee corresponderend geloof is een raakpunt aan de cirkel van mens en wereld. Meer niet. Vandaar, dat voor B. het verleden van de mens, dat hij met zich meedraagt door het heden naar de toekomst, niet anders dan het verleden van een permanente zelf-verzekering is, uitlopend en culminerend in de zelfverzekering tegenover God, en dat God steeds opnieuw in een "heden der genade-verkondiging" de mens van dit verleden moet bevrijden en bevrijdt. De er uit resulterende daden der naastenliefde kunnen bij B. daarom ook nooit tot werken der naastenliefde worden. Wat voor zoden deze daden der naastenliefde aan de dijk zetten, blijft dientengevolge volslagen in het duister. Want in elk geval moet in elk nieuw actueel heden der genade-verkondiging de mens van zichzelf bevrijd worden, d.i. van zijn verleden, en dat verleden kan niet anders zijn dan een verleden, dat door de (Farizeese) wil tot zelfbeveiliging tegenover God's komend oordeel wordt aangedreven, zelfbe- 
veiliging tegenover de straf Gods en vanuit de angst voor God.

Uit het christelijk geloof neemt $\mathbf{B}$. dan over, dat uit 's mensen zondigheid geen zelfverlossing mogelijk is. Verlossing, bevrijding van zichzelf uit eigen wil en werk der zelf-beveiliging is enkel mogelijk door Gods openbarende genade en genadeopenbaring in de actuele Christus-verkondiging.

Geen zelfbevrijding is mogelijk. En derhalve ook geen vrijheid tenzij door Gods vergevende genade-daad in elk nieuw actueel heden.

Met deze theologie komt $B$. overhoop te liggen met alle existentie-filosoof, niet alleen met Sartre, maar ook met Jaspers, en niet alleen met Jaspers, maar ook met de Heidegger van "Sein und Zeit". Hij komt daarmee overhoop te liggen met het humanisme in de existentie-filosofie en in de existentiefilosofische vrijheidsidee, of - zo ge wilt - het existentiefilosofisch vrijheidsgeloof als geloof in de mens en in de mens alleen.

Maar B. houdt moedig stand. Dit openbarings- en genadegeloof, dat hem ook van alle oud-liberale en oud-modernistische theologie onderscheidt, blijft de kern van zijn theologie. God, Die in goddelijke vrijheid als vergevend God uit Zijn toekomst op ons toe komt in het kerugma des kruises. Hij hoeft hiervan geen verantwoording af te leggen, heeft geen behoefte aan apologetiek, omdat hij zichzelf beveiligd heeft met het groot Apologeticum van: de Paradox.

Op deze wijze meent hij te kunnen evangeliseren onder de moderne intellectuelen. De paradox is de evangelisatie-sleutel. En de inhoud der prediking is de boodschap van de transcendente God, Die ons van alle zelf-verzekering bevrijdt door het Woord en de Openbaring van Zijn genade. Dat als „Ereignis” mij in de eenzaamheid van mijn geloofsbeslissing ontmoet en bevrijdt van mijzelf tot de openheid voor medemens, donker noodlot en de steeds weer genadig tot mij komende God. Dat mij van alle zekerheden berooft, en mij ongedwongen, zonder kramp, open stelt.

Hoezeer hij hierin ook van de oud-liberale theologie verschilt, vergeten wij niet, dat B. "ontmythologiseert" de Bijbelse openbaring inzake Christus' borgtochtelijk lijden, en eveneens de Bijbelse openbaring inzake de opstanding van Christus. Dit te moeten geloven, is niet minder dan de eis van een „sacrificium intellectus". Ook de paradox kan hier geen hulp bieden. 
De synthese heeft derhalve ten gevolg, dat geen existentiefilosoof hem bij kan vallen, en dat B.'s poging, om binnen de „Existenzial-Analytik” aan de "Gottesfrage” als de verholen vraag, die in ieder mens wezenlijk aanwezig zou zijn, zonder dat hij zich hiervan bewust hoeft te zijn, een plaats te geven, in strijd is met alle existentie-philosophie. Het feit van Gods eschatologische heilsopenbaring en van Gods eschatologisch openbaringsheil is derhalve verrassend; de mogelijkheid er toe zou reeds in een „Existenzial"-analyse van de mens kunnen worden blootgelegd: Zo de nieuwe existentie-filosofie van Bultmann.

Ze heeft aan de andere zijde tot gevolg, dat de Bijbelse openbaring inzake God en Zijn heil aanzienlijk wordt gereduceerd, ja zelfs verkracht, zoals duidelijk blijkt uit de loochening van Christus' borgtochtelijk lijden en uit de loochening van de Opstanding van Christus. Vandaar, dat de paradox niet zo zware last op zijn schouders krijgt.

De existentie-filosofische anthropologie convergeert reeds naar B.'s theologische anthropologie, en zijn theologische anthropologie convergeert reeds naar zijn existentie-filosofische anthropologie. Vandaar, dat noch het humanistisch existentialisme noch het Schriftgelovig belijden van de orthodoxie - Lutherse, Gereformeerde, Rooms-Katholieke en Oosters-Orthodoxe - met $\mathrm{B}$. in zee gaat.

Begrijpelijk is echter, dat B. dit orthodoxe geloof bestrijdt met wapenen aan de existentie-filosofie, en het humanistischexistentialisme bestrjidt met wapenen aan de orthodoxe belijdenis van de rechtvaardigmaking-door-het-geloof alleen ontleend. Maar vandaar ook, dat geen van beide bestreden partijen zich door B.'s bestrijding weerlegd acht. $\mathrm{Er}$ is niet eens een gemeenschappelijke gespreksbasis.

7. Twee van de meest interessante bladzijden uit B.'s oeuvre zijn de slotpagina's uit B.'s artikel „Das Befremdliche des christlichen Glaubens" (G.u.V., III, 211 en 212). Hij polemiseert daar met Jaspers. Jaspers staat niet open voor B.'s dialektische verbinding van Gods (actuele) openbaring met het historisch gebeuren (van Jezus Christus, culminerend in Zijn kruisdood), evenmin voor B.'s centrale aandacht voor Christus' kruis.

B. nu is van oordeel, dat dit verklaarbaar is. Hij schrijft: „Er (n.l. Jaspers) ist offenbar nicht bereit, sich gegenüber dem ihm hier und jetzt begegnenden Wort Gottes völlig zu ent- 
sichern, es schlechterdings hier und jetzt Ereignis werden zu lassen... Er sichert sich gleichsam durch eine Metaphysik, in der vorgezeichnet ist, wann und wo Gott reden könne. Es scheint mir, dasz er um seiner Selbstsicherung willen Gott, der immer nur ein auf mich zukommender Gott sein kann, zu einer zeitlosen Welt des Geistes vergegenständlicht, über die der Mensch denkend verfügen kann" (G.u.V., III, 211, 212).

Wat zou Jaspers hiervan zeggen? Mij Jaspers indenkende, komt het mij voor, dat deze argumentatie voor Jaspers geen hout snijdt. Jaspers ontkent n.l. niet de geldigheid van B.'s theologie omdat hij zichzelf beveiligen wil tegen God, maar hij ontkent haar, omdat hij eigen vrijheid beveiligen wil tegen de willekeur van B.'s paradox. Vanuit de existentie-filosofische presuppositie's (van Jaspers én van B.) volkomen terecht. B.'s machtsspreuk van de paradox is een nachtspreuk voor Jaspers. Naar aanleiding van Kierkegaard's paradox-leer merkte hij al eens op, dat het christendom hiermee blijk gaf, dat het over de kop geslagen was, en zich niet langer handhaven kon. Men moet, wil men B. volgen, niet alleen in "Glaubensentscheidung" geloven in Gods steeds nieuwe, actuele openbaringsgenade en genade-openbaring, maar men moet, om dit te kunnen, ook in B.'s paradox geloven. B. ziet dat over het hoofd, en heeft op grond van de ruimte, die dit paradox-geloof hem geeft, reden, om Jaspers te verwijten, dat hij een metafysica aanhangt, waarin hij zichzelf beveiligt tegen God.

Maar waar komt B.'s zekerheid omtrent de God der genade, die alleen een ,auf mich zukommender Gott sein kann"(!), vandaan? Zelf drijft hij ook een bepaalde metafysica, wanneer hij neerschrijft, wat God alleen maar kán zijn (geen Schriftgelovige, die hem hierin bijvalt, en die hem dan niet hetzelfde verwijt als hij aan Jaspers verwijt!); maar bovendien is hij hier a.h.w. de paradox voorbij en meent hij, Jaspers te kunnen ontmoeten op het gemeenschappelijke vlak: vrijheid drijft zekerheid uit; zekerheid vrijheid; het eerste is legitiem; het tweede is zelfverraad van de mens aan zichzelf. Om dan Jaspers te verwijten, dat hij zichzelf in een bepaalde metafysica zou beveiligen. Alsof de existentie-filosofie, en ook de in deze filosofie geïnoculeerde, theologie van B. zichzelf als vrijblijvend zou aandienen aan de mens. $\mathrm{Zij}$ doen dat niet. Zij beschuldigen zelfs de mens, die niet existentiëel leeft naar het patroon dezer filosofie, dat hij een oneigenlijk mens is, en ze zijn hier zeker van op basis van de door hen algemeen- 
geldige gedachte Existenzial-Analytik. Wanneer B. in deze passage Jaspers verwijt, dat hij blijkbaar een standpunt buiten de geschiedenis inneemt, van waaruit hij een historisch feit meent te kunnen beoordelen, dan valt $B$. toch in ditzelfde zwaard, wanneer hij meent te kunnen oordelen, dat Christus niet voor zondaren gestorven kan zijn en dat hij niet kan zijn opgestaan uit de doden. Zijn restant van christelijk geloof staat dan ook op zeer losse schroeven, omdat hij evenals J. uitgaat van de zekerheid der menselijke vrijheid, d.i. der menselijke zelfbeschikkingsmacht, en deze zekerheid doorkruist, hoogst gewelddadig, met de paradox van het geloof, dat de mens steeds weer onvrij is en onvrij moet zijn, en steeds weer uit deze onvrijheid enkel bevrijd kan worden door de coöperatie van 's mensen "Selbst-Entsicherung" met Gods genadige bevrijding en overzetting in de nieuwe aeoon van de nieuwe, eschatologische "Gegenwart", tot de reële vrijheid der openheid voor de toekomst. Zodat vrijheid en zekerheid elkander niet alleen bij Jaspers, maar ook bij Bultmann ontmoeten, en de zekerheid zelfs de vrijheid garandeert: bij Jaspers in de humanistische leer van de vrijheid, die slechts uit eigen oorsprong vrijheid kan zijn; en bij Bultmann in de humanistisch-paradoxaal-christelijke leer, volgens welke vrijheid slechts uit de paradoxale ontmoeting van menselijke „Entscheidung" en goddelijke "Entscheidung" in het ogenblik van het historisch-eschatologische heden kan ontstaan.

Dat Bultmann Jaspers' bestrijding van eigen vrijheidsleer slechts kan zien en wel moet zien als "Selbst-Sicherung" van de persoon van Jaspers, volgt met innerlijke, metafysicaaltheologische noodzaak uit B.'s vrijheidsleer. En dat Jaspers deze „verklaring" van eigen verweer rustig, zo niet verontwaardigd, naast zich neer legt, volgt met even innerlijk-metafysicale noodzaak uit Jaspers' vrijheidsleer. En elk van beide is maar niet zo "vrij", om de ander zo te zien, maar elk van beide is er zeker van, dat hij de ander zo goed ziet. Communicatie is er niet. Ze is, zolang zij beiden zeker zijn van eigen vrijheidsleer, ook niet mogelijk. Vandaar, dat B. het ergste verwijt, dat hij kent, Jaspers naar het hoofd slingert: Jaspers wil zich niet „entsichern”. Alsof B. zich zou hebben „entsichert”: hij weet zelfs in deze zelfde passage, dat "Gott immer nur ein auf mich zukommender Gott sein kann"!

8. Zijn tweeslachtige positie komt, indien nodig, nog eens helder aan het licht, wanneer hij op dezelfde pagina een 
beroep doet op Heidegger. Maar dan niet op de Heidegger van „Sein und Zeit", maar nota bene op de Heidegger van na „die Kehre": die Heidegger, die later bij leerlingen van Bultmann, zoals Ernst Fuchs, autoritatief zal zijn, en die hij later in zijn leerlingen zal bestrijden.

De Heidegger van de neo-speculatieve Zijns-leer leert, om ook de "metaphysische wil van het willen funderen" op te geven, en zo de zelfhandhavingswil, die aan alle metafysica eigen is, prijs te geven. De overwinning der metafysica is „die Kehre des Selbstverständnisses der Existenz" (a.w. 212).

Bultmann grijpt dit aan, om claarmede te „klären, was überhaupt ein im Hier und Jetzt begegnendes Wort als sich ereignende Anrede Gottes bedeuten kann". Men lette weer op dit „kunnen". Het wijst op de grond der mogelijkheid, welke mogelijkheidsgrond de filosoof als filosoof kan onthullen, en waarbinnen alle realiteit, ook in dit geval die van Gods actuele Woord, dat in het heden der genade vrijmaakt, plaats moet vinden.

Maar dit beroep op Heidegger houdt ook in, dat alles, wat B. tot nu toe leerde als "Existenzial-Analytik" geloochend wordt. Geloofs-beslissing is voortaan ook bij Heidegger een daad van het $\mathrm{Zijn}$, die de mens in de "Lichtung van het $\mathrm{Zijn"}$ plaatst, zonder dat er iets aan de mens wordt gevraagd. Van een paradox is dan ook geen sprake meer. $\mathrm{Zij}$ is niet meer nodig, want het ,zelf" van de mens ligt buiten hem, en wordt van buiten aan hem geschonken; het wordt hem toegeworpen.

Maar bovendien is daarmede voor $\mathrm{H}$. de laatste grond van het geloof in God aan dit geloof ontnomen. God behoort evenals een mens, een sprinkhaan en een slaapkamerameublement tot het zijnde. Hij is allerminst het Zijn. Vandaar, dat de Zijnsopenbaring voor Heidegger iets totaal anders is dan de zelfopenbaring van ,een god of van goden". Het zelf-zijn van God is in deze nieuwe Zijns-leer in principe onderwoeld. Daarmee ook het zelf-zijn van de mens.

Bultmann kan op deze nieuwe zijnsleer een beroep doen, omdat hij zich met behulp van haar kan ontdoen van de existentie-filosofische vrijheidsleer en haar anthropocentrisch humanisme. En hij doet het hier dan ook. Maar zelf blijkt hij hier toch wel gevaar te zien. Want onmiddellik distanciëert hij zich er van, door te schrijven: „Es versteht sich von selbst, dasz solche Reflexion nicht eine Legitimation des begegnenden Wortes Gottes im christlichen Sinne sein kann". 
Hier moeten wij het mee doen: „Het spreekt vanzelf”. Maar waarom dan een beroep op Heidegger gedaan? En waarom dan wel volgehouden, dat Heidegger's leer het christelijk geloof in het "Ereignis" van het actuele Woord Gods in de „Gegenwart" kan ,klären"?

Heidegger's leer kan haar ,klären" wanneer zowel de voorafgaande Existenzial-Analytik" als ook de Paradox ondersteboven zijn gelopen. Dat er dan echter een nieuwe metafysica ontstaan, die van het "Zijn van het Zijn", moet B. dan even op de koop toe nemen. Evenals de nieuwe zekerheid, die deze nieuwe metafysica biedt. Inderdaad, het spreekt vanzelf, dat B. weer haastig afscheid moet nemen van deze Heidegger. Om met de ouderwetse Existenzial-Analytik en de Paradoxleer weer verder in zee te gaan. Hij wil dan ook niet met behulp van deze nieuwe Heidegger een soort apologetiek van het christelijk geloof schrijven. Het zou o.i. ook alleen maar een nieuwe aporetiek kunnen worden. Een aporetiek, waarin Heidegger's Zijnsleer en de Bijbelse openbaringsleer beide op het Procrustusbed ener nieuwe paradoxalistische synthese zouden worden gepijnigd en misvormd. Maar dusdoende is B. niet van J. af. Met zijn beroep op Heidegger werpt hij de duivel met de duivel uit. Haastig keert hij daarom op zijn schreden terug. Om in zijn oude "zekerheid" en de vrijheid, resp. het geloof in deze zekerheid, terug te vallen: De Zekerheid van de Existenzial-Analytische anthropologie verbonden met de Zekerheid van de Paradox-theologie, die de synthese van humanistische vrijheidsleer en het door B. behouden restant van de christelijkBijbelse Openbaringsleer tot stand moet brengen. In een ge loofs-zekerheid: Inzake menselijke vrijheid, inzake de theoretische paradox en inzake de goddelijke genade-vrijheid, verbonden aan het „Ereignis" der verkondiging.

En weer ontmoeten elkaar vrijheid en zekerheid. En wij ontdekken, dat B. zijn zekerheid gevonden heeft in deze synthese. Vervolgens, dat hij met deze synthese zijn vryheidsleer "redt" als de leer van vrijheid in onzekerheid. Met één uitzondering: Zijn leer van goddelijke en menselijke vrijheid is geen moment onzeker. $\mathrm{Zij}$ staat bij hem buiten discussie. En terwijl hij iedere keer en ieder mens meent te moeten "entsichern", kan hij niet nalaten, bij herhaling te schrijven, wie God wel en niet "kan" zijn, en wie God dus wel "moet" zijn; wie de mens wel en niet kan zijn, en wie hij dus wel moet zijn. Zekerheid, die aan vrijheid voorafgaat. Een geloofzeker- 
heid, die als zodanig niet expliciet uit de verf komt, omdat Bultmann verslaafd is aan zijn Heidegger van "Sein und Zeit", aan zijn paradox van Kierkegaard, en aan zijn restant van een Schriftuurlijk Godsgeloof. Hij zou grote ogen opzetten, als iemand hem zou zeggen, dat het nu eindelijk eens tijd wordt, dat hij zich hiervan laat „entsichern”. Naar eigen recept. Want hij zou nog dieper wegzinken dan de nihilist. Die immers van het goed recht van eigen nihilisme nog zeker is. Ook dat niet. Neen, ook dat niet. En wij duizelen gediaboliseerd weg in minder dan „Het Niets”. Dan eerst is vrijheid wezenlijk correlaat met onzekerheid. De existentie-filosofische en de paradoxaal-theologische correlatie van vrijheid duurt ook maar zolang als zij duurt.

S. U. Zuidema.

Amsterdam 